\title{
Climate Change Impacts on Maize Production in the Warm Heart of Africa
}

\author{
Kondwani Msowoya ${ }^{1} \cdot$ Kaveh Madani $^{2}$. \\ Rahman Davtalab $^{1} \cdot$ Ali Mirchi $^{3}$ - Jay R. Lund ${ }^{4}$
}

Received: 13 October 2015 / Accepted: 26 August 2016/

Published online: 6 September 2016

(C) The Author(s) 2016. This article is published with open access at Springerlink.com

\begin{abstract}
Agriculture is the mainstay of economy in Malawi - the warm heart of Africa. It employs $85 \%$ of the labour force, and produces one third of the Gross Domestic Product (GDP) and $90 \%$ of foreign exchange earnings. Maize farming covers over $92 \%$ of Malawi's agricultural land and contributes over $54 \%$ of national caloric intake. With a subtropical climate and $\sim 99 \%$ rainfed agriculture, Malawi relies heavily on precipitation for its agricultural production. Given the significance of rainfed maize for the nation's labour force and GDP, we have investigated climate change effects on this staple crop. We show that rainfed maize production in the Lilongwe District, the largest maize growing district in Malawi, may decrease up to $14 \%$ by mid-century due to climate change, rising to as much as $33 \%$ loss by the century's end. These declines can substantially harm Malawi's food production and socioeconomic status. Supplemental irrigation, crop diversification and natural conservation methods are promising adaptation strategies to improve Malawi's food security and socioeconomic stability.
\end{abstract}

Keywords Climate change $\cdot$ Maize $\cdot$ Corn $\cdot$ Rainfed agriculture $\cdot$ Food security $\cdot$ Malawi Lilongwe District

Kaveh Madani

k.madani@imperial.ac.uk

1 Department of Civil, Environmental and Construction Engineering, University of Central Florida, Orlando, FL 32816, USA

2 Centre for Environmental Policy, Imperial College London, London SW7 2AZ, UK

3 Department of Civil Engineering and Center for Environmental Resource Management, The University of Texas at El Paso, El Paso, TX 79968, USA

4 Department of Civil and Environmental Engineering, University of California, Davis, CA 95616, USA 


\section{Introduction}

Climate change impacts on agricultural crop production vary from place to place (Muller et al. 2011) and from crop to crop (Tubiello et al. 2002). Higher temperatures can reduce crop production in parts of the world (Schlenker and Lobell 2010; Gohari et al. 2013) although crop yield could increase with warm-wet climate change in some areas (Chavas et al. 2009). Longterm implications of crop yield reduction are significant for food security (Ringler et al. 2010), socioeconomic stability (Burke et al. 2009), and ecological integrity (Walker and Schulze 2008). These risks are particularly high for the less resilient impoverished countries (Mendelsohn 2008; Muller et al. 2011).

Agricultural production in tropical and subtropical areas of Africa is more sensitive to climate warming than temperate agriculture (Mendelsohn 2008). Frequent droughts and floods in the sub-Saharan Africa increase food insecurity, water scarcity, and famine, reflecting the region's vulnerability to climate change (Ngingi 2009). Warning signals of the adverse effects of climate change in sub-Saharan Africa are manifest in higher food prices and reduced calorie availability which cause malnutrition (Ringler et al. 2010).

Different methods have been proposed to deal with high uncertainty associated with general circulation models (GCMs), which are the prevailing tool for climate projection. These include (i) using central prediction with error bars, (ii) expressing the results as a central prediction, (iii) applying a bounded range with a known probability distribution and (iv) using a bounded range with an unknown probability distribution (OECD 2004). GCMs have limited capability at local scales, although they can simulate climate at a global scale. There are different methods for downscaling GCM outputs which fall under two headings (i) dynamic and (ii) statistical downscaling (Wilby et al. 1998; Fowler et al. 2007). A commonly used statistical downscaling technique employs stochastic weather generators (WG) (Semenov and Barrow 2002). In this study, a bounded range with a known probability distribution and a stochastic WG were applied to handle the uncertainty of the GCMs; a statistical downscaling approach that has been previously implemented in climate change studies on crop production (Gohari et al. 2013; Gohari et al. 2014).

Rainfed agriculture is the mainstay of Malawi's economy, a landlocked country dubbed the warm heart of Africa. The country has a subtropical climate with three seasons. The cool dry winter runs from May to August with mean temperatures between $17{ }^{\circ} \mathrm{C}$ and $27{ }^{\circ} \mathrm{C}$, and minimum temperature from $-3{ }^{\circ} \mathrm{C}$ to $10{ }^{\circ} \mathrm{C}$, particularly in June and July. This is followed by a hot and dry season between September and October when temperatures can reach $37{ }^{\circ} \mathrm{C}$ with 50-80\% humidity. About $95 \%$ of annual precipitation falls in the warm-wet season between November and April, with February being the wettest month (MDCCMS 2015). The trends in the national Malawian GDP are greatly influenced by agricultural activities that provide $85 \%$ of employment (GoM 2011a) and $83 \%$ of foreign exchange income (Mucavele 2006), contributing to $27 \%$ of the GDP (World Bank 2015). The growing population in Malawi, reported at 16.8 million in 2014 (World Bank 2015), drives low crop production primarily due to factors such as loss of agricultural land, as well as continuous farming and deforestation which cause soil erosion and low fertility levels (Tchale 2009).

The country's economy and food production could be greatly impacted by climate change through changes in rainfed maize yield. Maize is Malawi's staple food crop cultivated by up to $97 \%$ of the farmers (Minot 2010), making up over $54 \%$ of the caloric intake (Minot 2010). Over the last few decades, corn production has been affected by precipitation variability and changes in temperature. Droughts of the 1990s 
and 2000s significantly reduced maize production and led to famine in many areas of Malawi (GoM 2011b). After the drought in 2005, the introduction of a Farm Input Subsidy Programme (FISP) by the Government of Malawi (GoM), resulted in increased corn harvests between 2006 and 2009 (Denning et al. 2009; Dorward and Chirwa 2011) and a significant reduction in maize imports due to increased national food security (Dorward and Chirwa 2011). Despite the FISP, the GoM advocates for the implementation of other strategies that will enable the country to maintain stable food supplies under climate change (GoM 2011b).

Understanding the impacts of climate change on rainfed agriculture is necessary to draw attention to the need for minimizing undesirable effects in Malawi. This paper presents the outcomes of an original assessment of climate change impacts on Malawi's rainfed maize production. It focuses on the Lilongwe District, which is located in the central region of Malawi at latitude $13^{\circ} 30^{\prime}$ South, longitude $33^{\circ} 37^{\prime}$ East and an elevation of $1133 \mathrm{~m}$ above sea level (Fig. 1), and has similar average annual temperatures and precipitation as other maize-growing areas in Malawi. Over the past decade, average maize yields per hectare in Lilongwe District have nearly equalled the national maize yields, making it a suitable region for investigating the potential effects of climate change on maize production in this African nation.

Fig. 1 Map of Malawi and location of Lilongwe District (SMP 2006)

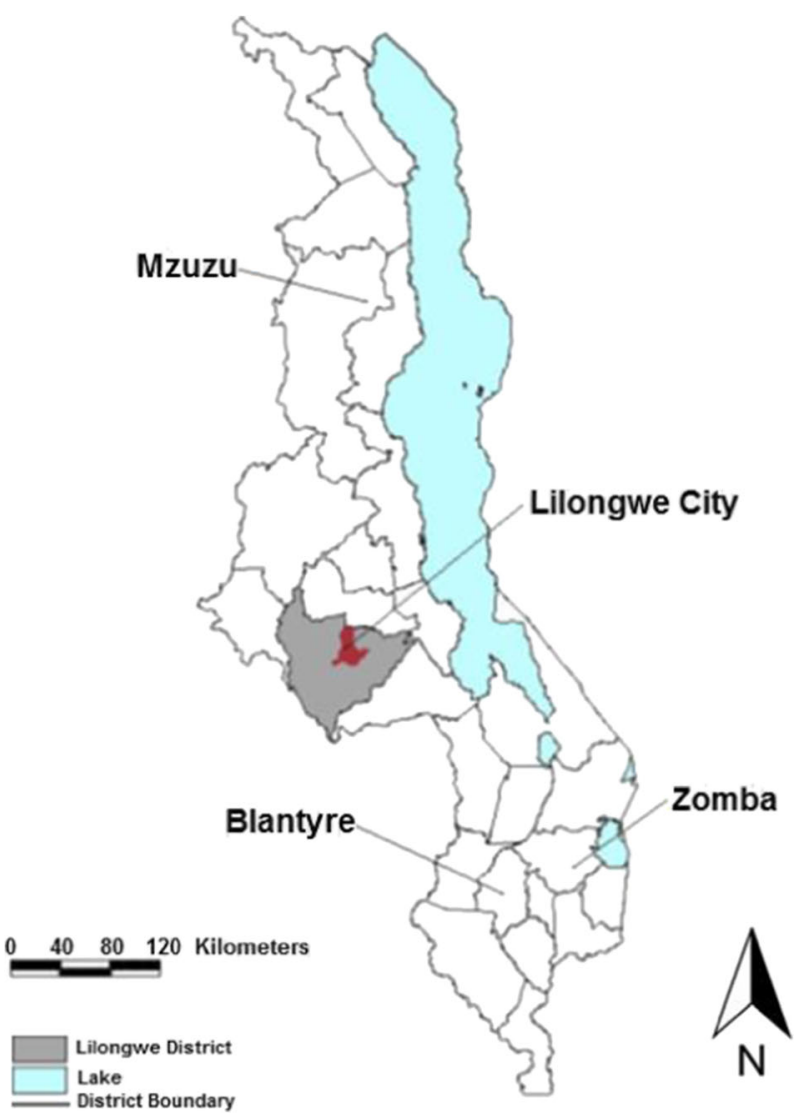




\section{Methods}

We used an ensemble of fifteen GCMs, under two emission scenarios - A1B emission scenario (SRA1B) and B1 emission scenario (SRB1) - to project long-term (multiple decades) changes in climate variables in 2046-2065 (2050s) and 2080-2099 (2090s). The details of the GCMs, from the Fourth Assessment Report (AR4) of the IPCC available at the time of completing this research, are summarized in Table 1. The SRA1B scenario assumes rapid population growth that peaks mid-century before declining, rapid economic growth and the development of new and efficient technologies (Nakicenovic and Swart 2000). The SRB1 scenario is characterized by a similar population trend but with a change in the economic structure which diversifies to service and information with the introduction of clean and resource efficient technologies that focus on social and environmental sustainability (Nakicenovic and Swart 2000). The long-term climate changes were compared to a baseline period of 1971-2000. The historical observed weather data used in this study was obtained from the Department of Climate Change and Meteorological Services in the Ministry of Natural Resources, Energy and Environment in Malawi. The data were collected from the Chitedze Research Station, the main meteorological station in Lilongwe District.

The Long Ashton Weather Generator (LARS-WG; Semenov and Barrow 2002) was used to downscale the GCM outputs. The WG simulated weather data at a single site under historical and future conditions for the GCMs which were developed under the

Table 1 Description of the fifteen GCMs (Semenov 2014)

\begin{tabular}{|c|c|c|c|c|}
\hline Centre & Centre Acronym & Country & Global Climate Model & Grid Resolution \\
\hline Beijing Climate Centre & $\mathrm{BCC}$ & China & BCC-CM1 & $1.9^{\circ} \times 1.9^{\circ}$ \\
\hline $\begin{array}{l}\text { Canadian Centre for } \\
\text { Modeling and Analysis }\end{array}$ & CCCma & Canada & CGCM3 (T47) & $2.8^{\circ} \times 2.8^{\circ}$ \\
\hline $\begin{array}{l}\text { Centre National de Recherches } \\
\text { Meteorologiques }\end{array}$ & CNRM & France & CNRM-CM3 & $1.9^{\circ} \times 1.9^{\circ}$ \\
\hline $\begin{array}{l}\text { Australia's Commonwealth } \\
\text { Scientific and Industrial } \\
\text { Research Organisation }\end{array}$ & CSIRO & Australia & CSIRO-MK3.0 & $1.9^{\circ} \times 1.9^{\circ}$ \\
\hline Institute of Atmospheric Physics & LASG & China & FGOALS-g1.0 & $2.8^{\circ} \times 2.8^{\circ}$ \\
\hline Goddard Institute for Space Studies & GISS & USA & GISS-AOM & $3^{\circ} \times 4^{\circ}$ \\
\hline $\begin{array}{l}\text { Geophysical Fluid Dynamics } \\
\text { Laboratory }\end{array}$ & GFDL & USA & GFDL-CM2.1 & $2.0^{\circ} \times 2.5^{\circ}$ \\
\hline UK Met. Office & UKMO & UK & HadCM3 & $2.5^{\circ} \times 3.75^{\circ}$ \\
\hline UK Met. Office & UKMO & UK & HadGEM1 & $1.3^{\circ} \times 1.9^{\circ}$ \\
\hline Institute for Numerical Mathematics & INM & Russia & INM-CM3.0 & $4^{\circ} \times 5^{\circ}$ \\
\hline Institute Pierre Simon Laplace & IPSL & France & IPSL-CM4 & $2.5^{\circ} \times 3.75^{\circ}$ \\
\hline $\begin{array}{l}\text { Meteorological Research } \\
\text { Institute, Japan }\end{array}$ & NIES & Japan & MIROC3.2 (hires) & $1.1^{\circ} \times 1.1^{\circ}$ \\
\hline $\begin{array}{l}\text { Max-Planck Institute } \\
\text { for Meteorology }\end{array}$ & MPI-M & Germany & ECHAM5-OM & $1.9^{\circ} \times 1.9^{\circ}$ \\
\hline $\begin{array}{l}\text { National Centre for } \\
\text { Atmospheric Research }\end{array}$ & NCAR & USA & PCM & $2.8^{\circ} \times 2.8^{\circ}$ \\
\hline $\begin{array}{l}\text { National Centre for } \\
\text { Atmospheric Research }\end{array}$ & NCAR & USA & CCSM3 & $1.4^{\circ} \times 1.4^{\circ}$ \\
\hline
\end{tabular}


AR4. The simulated data were in daily time series for different climate variables including, maximum and minimum temperature $\left({ }^{\circ} \mathrm{C}\right)$, precipitation $(\mathrm{mm})$ and solar radiation $\left(\mathrm{MJmm}^{-2} \mathrm{day}^{-1}\right)$. In the absence of solar radiation, the LARS-WG accommodates the use of sunshine hours which it converts to solar radiation (Semenov and Barrow 2002). To capture the less frequent events like droughts and floods, (Semenov and Barrow 2002) recommend the use of observed daily weather data of at least 20 to 30 years. The observed weather data used in this study was from 1971 to 2000. In the calibration step, the observed weather data were used to generate probability distributions of the observed data; these were used to calculate the WG parameters (Semenov and Barrow 2002). Simulated data for the historical period were used in the LARS-WG validation process. Statistical indicators ( $\chi^{2}$ and $t$ tests) were applied to investigate the significance and the reliability of the LARS-WG to predict future climate data with reference to the 1971-2000 baseline period at a $5 \%$ confidence level. Once the performance of the LARS-WG was deemed satisfactory, synthetic weather data were generated for the aforementioned future periods and emission scenarios.

To account for the uncertainties, we applied a probability analysis method with bounded distribution functions (Gohari et al. 2013). The procedure involved three steps. In the first step, the ability of each of the fifteen GCMs to simulate precipitation and temperature variables was weighted based on the absolute difference between the observed data and the historical projections by the GCMs:

$$
W_{i j}=\frac{\left(\frac{1}{\Delta d_{i j}}\right)}{\sum_{j=1}^{N}\left(\frac{1}{\Delta d_{i j}}\right)}
$$

where: $W_{i j}$ is weight of GCM $j$ in month $i ; \Delta d_{i j}$ is the absolute difference in temperature or precipitation between the monthly mean simulated by $\operatorname{GCM} j$ in month $i$ of the baseline period and the corresponding observed value and $\mathrm{N}$ equals fifteen (the number of GCMs).

In the subsequent step, monthly discrete probability distribution functions (PDFs) for changes in climate parameters were generated based on the calculated weights (Fig. 2). The PDFs associate the weight of each GCM to average monthly changes in minimum and maximum temperature and precipitation (Gohari et al. 2013). In a process that has been

(a)

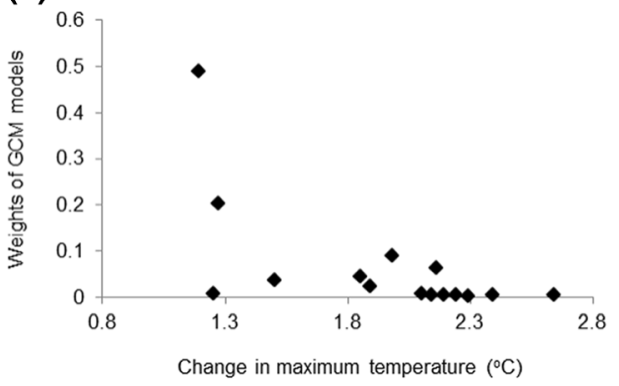

(b)

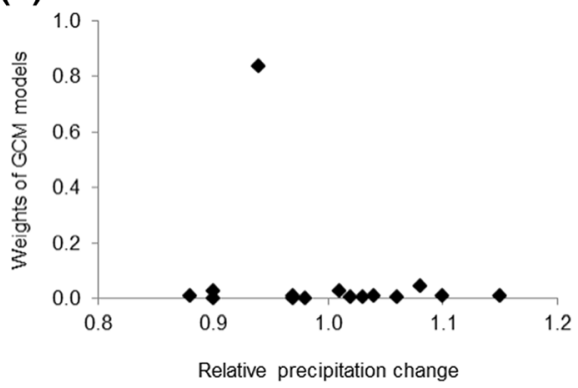

Fig. 2 Example discrete PDFs outlining the relationship between weights of the GCMs and monthly change in climate variables. Mid-century (2050s) showing a temperature changes in January and (b) relative precipitation changes in February 
successfully executed in other climate change impact studies (Ines and Hansen 2006; Piani et al. 2010; Gohari et al. 2013), the Gamma distribution function, with two parameters, was used to construct continuous PDFs:

$$
f(x)=\frac{1}{\beta^{\alpha} \Gamma(\alpha)} \chi^{\alpha-1} e^{-\chi / \beta} \quad ; x \geq 0
$$

where: $x$ is the climate variable; $\alpha$ and $\beta$ are the shape and scale parameters for the Gamma distribution function; and $\Gamma(\alpha)$ is the incomplete Gamma function which is given as:

$$
\Gamma(\alpha)=\int_{0}^{\infty} x^{\alpha-1} e^{-x} d x
$$

The values of $\alpha$ and $\beta$ were adjusted using the maximum likelihood estimation method. The sum of squared error was used to assess how well the Gamma distribution fit the data:

$$
S S E=\sum_{i=1}^{n}\left(y_{i}-¥_{i}\right)^{2}
$$

where: $y_{i}$ is the calculated weight for each GCM; $Y_{i}$ is the estimation of the beta function and $\mathrm{n}$ equals fifteen (the number of GCMs).

In the final step, we converted the PDFs to cumulative distribution functions (CDFs) (Fig. 3). The values of climate change variables at three probability percentiles (25th, 50th, and 75th) were then extracted from the generated CDFs to represent three maize production scenarios with different risk levels: high changes in precipitation and low changes in temperature (25th probability percentile); low changes in precipitation but high changes in temperature (75th probability percentile); median precipitation and temperature changes (50th probability percentile). With three types of climate variables, two emission scenarios and two future time periods in this study, 144 PDFs and CDFs were constructed to characterize the monthly relationships between the weight of each GCM and the average changes in precipitation, minimum temperature and maximum temperature.

AquaCrop (Steduto et al. 2009), the crop model developed by the Food and Agriculture Organization (FAO), was used to estimate potential crop production under different climate change scenarios as well as the historical climate. The model inputs include daily minimum and maximum temperature, precipitation, crop evapotranspiration and the mean annual carbon dioxide $\left(\mathrm{CO}_{2}\right)$ concentration (Steduto et al. 2009). The first three variables were sourced from the Malawian Department of Climate Change and Meteorological Services (MDCCMS), the

(a)

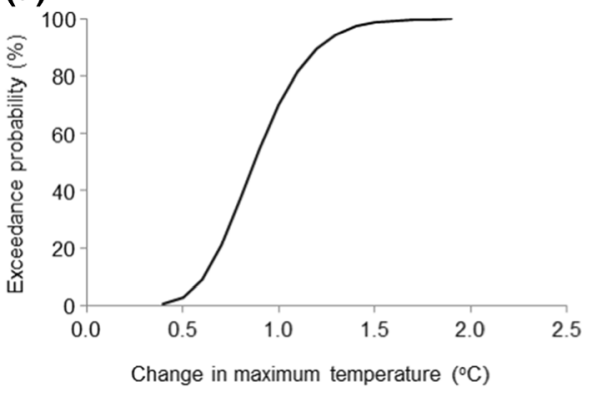

(b)

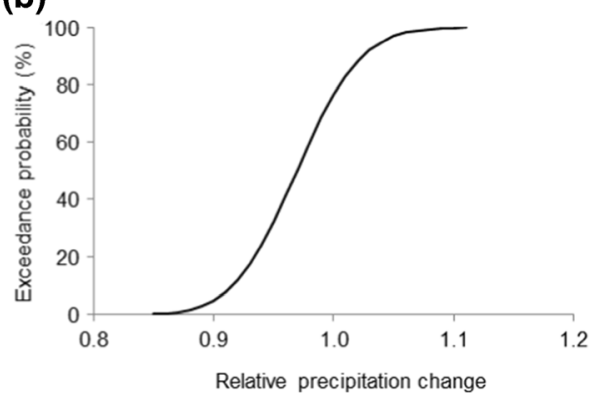

Fig. 3 Example CDFs developed based on the PDFs presented in Fig. 2 
evapotranspiration was calculated and the $\mathrm{CO}_{2}$ concentrations in the AquaCrop database originated from the Mauna Loa Observatory (Raes et al. 2012).

The linkages between the different variables in the AquaCrop model are shown in Fig. 4. The biomass is calculated using a fundamental equation, known as the 'AquaCrop growth engine' (Steduto et al. 2009) which considers both water productivity and transpiration (Raes et al. 2012):

$$
B=K s_{b} \times W P^{*} \times \sum \frac{T r}{E T_{o}}
$$

where: $B$ is the above-ground biomass $\left(\mathrm{g} \mathrm{m}^{-2}\right) ; K s_{b}$ is the air temperature stress coefficient (unit less); $W P^{*}$ is the water productivity i.e. biomass per unit of cumulative transpiration $\left(\mathrm{g} \mathrm{m}^{-2}\right)$; $T r$ is the crop transpiration $\left(\mathrm{mm} \mathrm{day}^{-1}\right)$ and $E T_{o}$ is the reference evapotranspiration $\left(\mathrm{mm} \mathrm{day}{ }^{-1}\right)$.

In the model crop yields are calculated based on the harvest index, the proportion of biomass that is yield (Steduto et al. 2009):

$$
Y=f_{H I} \times H I_{o} \times B
$$

where: $Y$ is the dry mass yield $\left(\mathrm{g} \mathrm{m}^{-2}\right) ; f_{H I}$ is the timing and magnitude of stress (unit less); $H I_{o}$ is the reference harvest index (fraction of biomass that is yield) (\%) and $B$ is the aboveground biomass $\left(\mathrm{g} \mathrm{m}^{-2}\right)$.

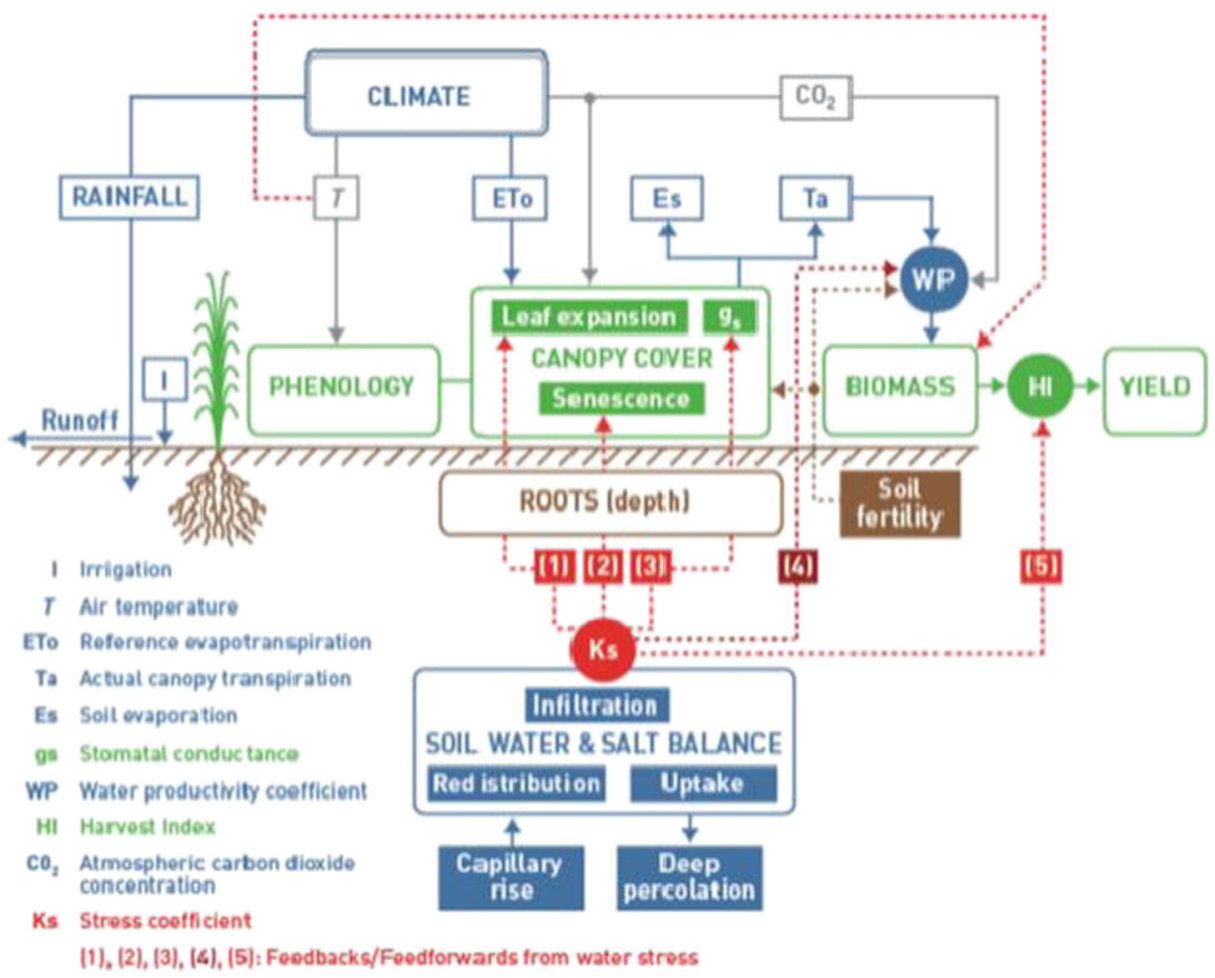

Fig. 4 The main components of the soil-plant-atmosphere continuum in AquaCrop (FAO 2009) 
The $\mathrm{ET}_{\mathrm{o}}$ Calculator (Allen et al. 1998) was used to estimate evapotranspiration based on Penman-Monteith algorithm under each scenario which is given by:

$$
\mathrm{ET}_{\mathrm{o}}=\frac{0.408 \Delta\left(\mathrm{R}_{\mathrm{n}}-\mathrm{G}\right)+\gamma \frac{900}{\mathrm{~T}+273} \mathrm{u}_{2}\left(\mathrm{e}_{\mathrm{s}}-\mathrm{e}_{\mathrm{a}}\right)}{\Delta+\gamma\left(1+0.34 \mathrm{u}_{2}\right)}
$$

where: $\mathrm{ET}_{\mathrm{o}}$ is the reference evapotranspiration $\left(\mathrm{mm} \mathrm{day}^{-1}\right) ; \mathrm{R}_{\mathrm{n}}$ is the net radiation at the crop surface $\left(\mathrm{MJ} \mathrm{m}^{-2}\right.$ day $\left.^{-1}\right)$; $\mathrm{G}$ is the soil heat flux density $\left(\mathrm{MJ} \mathrm{m}^{-2}\right.$ day $\left.{ }^{-1}\right)$; $\mathrm{T}$ is the mean daily air temperature at $2 \mathrm{~m}$ height $\left({ }^{\circ} \mathrm{C}\right) ; \mathrm{u}_{2}$ is the wind speed at $2 \mathrm{~m}$ height $\left(\mathrm{m} \mathrm{s}^{-1}\right) ; \mathrm{e}_{\mathrm{s}}$ is the saturation vapour pressure $(\mathrm{kPa}) ; \mathrm{e}_{\mathrm{a}}$ is the actual vapour pressure $(\mathrm{kPa}) ; \mathrm{e}_{\mathrm{s}}-\mathrm{e}_{\mathrm{a}}$ is the saturation vapour pressure deficit $(\mathrm{kPa}) ; \Delta$ is the slope vapour pressure curve $\left(\mathrm{kPa}^{\circ} \mathrm{C}^{-1}\right)$ and $\gamma$ is the psychometric constant $\left(\mathrm{kPa}^{\circ} \mathrm{C}^{-1}\right)$.

Based on the recorded maize yield in 2005 we calibrated the model by adjusting parameters that generated significant sensitivity, including crop, management and soil properties. We validated the model against the Lilongwe District's four-year (2000-2004) historical maize yield record using five statistical parameters: prediction error $\left(\mathrm{P}_{\mathrm{e}}=1.09 \%-9.88 \%\right)$, coefficient of determination $\left(\mathrm{R}^{2}=0.911\right)$, mean absolute error (MAE $\approx 0$ ), root mean square error ( $\mathrm{RMSE} \approx 0.09)$, and model efficiency $(\mathrm{E}=0.91)$. $\mathrm{E}$ and $\mathrm{R}^{2}$ indicate the predictive power of the model while $\mathrm{P}_{\mathrm{e}}, \mathrm{MAE}$ and RMSE denote the magnitude of error associated with the model prediction (Abedinpour et al. 2012). The model is said to perform better when values of $E$ and $\mathrm{R}^{2}$ approach one and when values of $\mathrm{P}_{\mathrm{e}}$, MAE and RMSE approach zero. Thus, the model's performance was satisfactory and it was considered to be reliable for making projections.

\section{Results}

The outputs from fifteen GCMs from two emission scenarios were downscaled by the LARSWG. The results from the statistical tests that were applied to assess the WG performance are given in Table 2. The relatively low values of $\chi^{2}$ and t tests and relatively high $p$-values were used as an indication of the model satisfactorily simulating future climate variables.

The GCM outputs indicate that the mean monthly temperature is expected to increase in the future under climate change (Fig. 5). The box plots in Fig. 5 illustrate the range of uncertainty in ensemble projections. For example, under emission scenario A1B in 2050s (SRA1B2050s), the projected precipitation by all GCMs for the month of January approximately ranges between $210 \mathrm{~mm}$ to $260 \mathrm{~mm}$. The changes in relative precipitation will be more uncertain than temperature with increases in some months and reductions in others. The large interquartile ranges (length of the boxes) in Fig. 5 demonstrate the variability and uncertainty of GCM outputs. In an effort to manage the uncertainty of the GCM outputs, the study employed probability assessment of bounded range of known distribution. The procedure involved three steps: (i) weighting average precipitation and temperature variables for each GCM based on the absolute difference between the observed data and the historical projections by the GCMs; (ii) generating monthly discrete probability distribution functions (PDFs) for changes in climate parameters based on the calculated weights; (iii) converting PDFs to cumulative distribution functions (CDFs) using the Gamma probability distributions. The expected changes for each climate variable were determined at the $25 \%, 50 \%$ and $75 \%$ probability percentiles. 
Table 2 The statistical details of the LARS-WG validation results

\begin{tabular}{|c|c|c|c|c|c|c|c|c|c|c|c|c|}
\hline \multirow[b]{2}{*}{ Month } & \multicolumn{4}{|c|}{ Precipitation } & \multicolumn{4}{|c|}{ Maximum Temperature } & \multicolumn{4}{|c|}{ Maximum Temperature } \\
\hline & $x^{2}$ & $p$-value & $t$ & $p$-value & $x^{2}$ & $p$-value & $t$ & $p$-value & $x^{2}$ & $p$-value & $t$ & $p$-value \\
\hline Jan & 0.06 & 1.00 & 0.30 & 0.77 & 0.05 & 1.00 & 0.05 & 0.96 & 0.05 & 1.00 & 0.75 & 0.46 \\
\hline Feb & 0.07 & 1.00 & 0.48 & 0.63 & 0.05 & 1.00 & 0.14 & 0.97 & 0.05 & 1.00 & 0.26 & 0.79 \\
\hline Mar & 0.06 & 1.00 & 0.68 & 0.50 & 0.16 & 0.91 & 2.21 & 0.08 & 0.05 & 1.00 & 1.25 & 0.22 \\
\hline Apr & 0.08 & 1.00 & 0.25 & 0.81 & 0.11 & 1.00 & 1.60 & 0.11 & 0.11 & 1.00 & 0.39 & 0.70 \\
\hline May & 0.22 & 0.57 & 0.26 & 0.80 & 0.05 & 1.00 & 0.43 & 0.67 & 0.16 & 0.90 & 2.04 & 0.75 \\
\hline Jun & 0.31 & 0.19 & 0.33 & 0.74 & 0.11 & 1.00 & 0.86 & 0.39 & 0.11 & 1.00 & 0.28 & 0.78 \\
\hline Jul & 0.22 & 0.60 & 0.25 & 0.80 & 0.05 & 1.00 & 0.02 & 0.98 & 0.05 & 1.00 & 0.94 & 0.35 \\
\hline Aug & 0.39 & 0.14 & 0.96 & 0.34 & 0.11 & 1.00 & 1.31 & 0.19 & 0.05 & 1.00 & 0.07 & 0.95 \\
\hline Sep & 0.13 & 0.98 & 0.13 & 0.90 & 0.05 & 1.00 & 0.09 & 0.93 & 0.11 & 1.00 & 2.48 & 0.36 \\
\hline Oct & 0.07 & 1.00 & 0.13 & 0.90 & 0.11 & 1.00 & 1.31 & 0.19 & 0.11 & 1.00 & 1.78 & 0.18 \\
\hline Nov & 0.06 & 1.00 & 1.15 & 0.25 & 0.16 & 0.91 & 1.85 & 0.07 & 0.05 & 1.00 & 0.44 & 0.66 \\
\hline Dec & 0.06 & 1.00 & 0.39 & 0.70 & 0.11 & 1.00 & 0.34 & 0.74 & 0.05 & 1.00 & 0.22 & 0.83 \\
\hline
\end{tabular}

Changes in future precipitation under the SRA1B and the changes in maximum temperature for the SRB1 at three probability percentiles (25th, 50th, and 75th) are shown in Fig. 6 . The changes in monthly precipitation for each time period and different risk levels show decrease and increase patterns in the same month. Projected precipitation changes are greater under the SRA1B than the SRB1 in both time periods. On average, annual precipitation amounts are predicted to decrease by $0 \%$ to $26 \%$ and $3 \%$ to $29 \%$ in 2050 s and 2090 s, respectively.
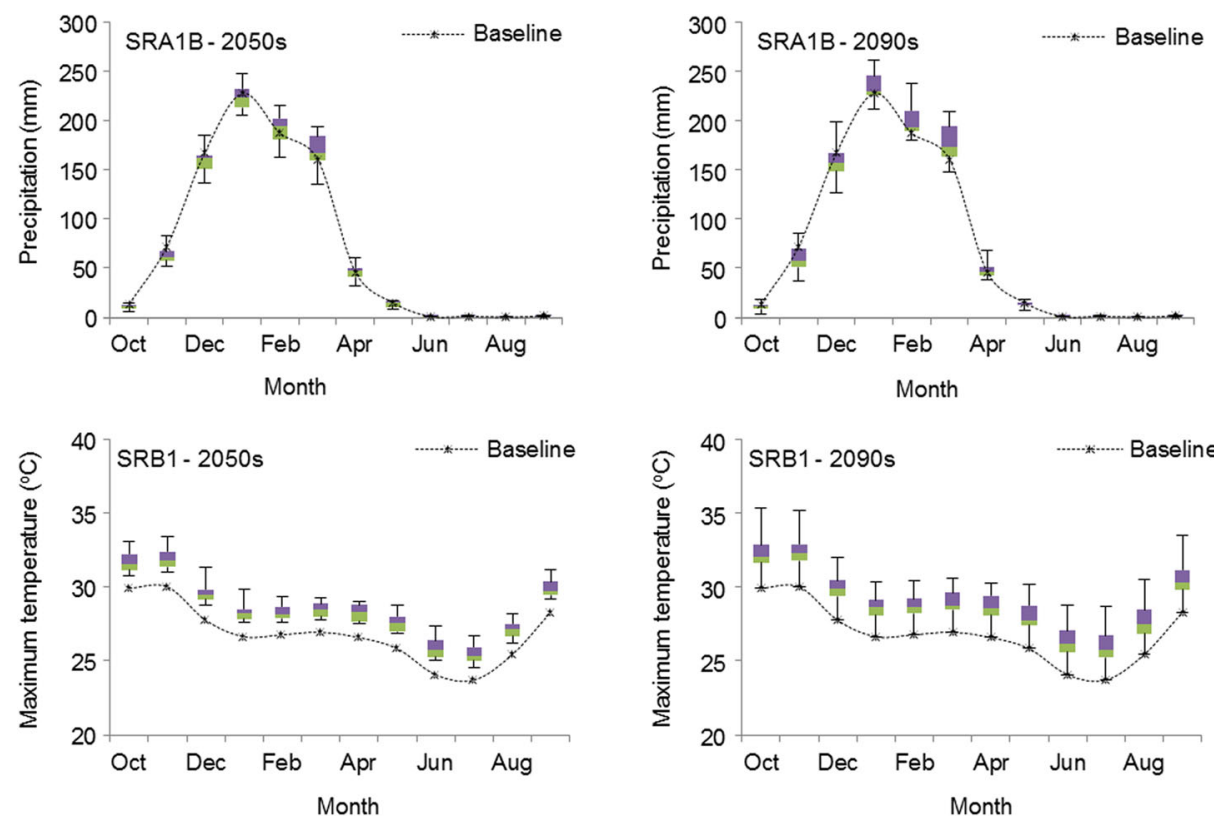

Fig. 5 Comparison of the baseline (1971-2000) mean monthly precipitation and maximum temperature with the projected mid- and end-century values for $\mathrm{A} 1 \mathrm{~B}$ and $\mathrm{B} 1$ emission scenarios 
Overall, maximum temperature is expected to increase in all cases, with greater temperature increases under SRA1B. Average mid-century minimum temperature changes may be $1.31^{\circ} \mathrm{C}$ to $2.15{ }^{\circ} \mathrm{C}$, increasing to $1.84{ }^{\circ} \mathrm{C}$ to $3.46{ }^{\circ} \mathrm{C}$ by the end of the century. Changes in the maximum temperature for the same time horizons may be, respectively, $1.26{ }^{\circ} \mathrm{C}$ to $2.20^{\circ} \mathrm{C}$ and $1.78{ }^{\circ} \mathrm{C}$ to $3.58{ }^{\circ} \mathrm{C}$ (Fig. 6). Projected temperature trends agree with findings of previous studies in sub-Saharan Africa (IPCC 2007) and temperature projections for Malawi (EAD 2002). Although the decrease in mean annual precipitation could be greater than what was previously reported which was a range from $16 \%$ to $-22 \%$ change in annual precipitation relative to the 1960-1991 baseline (EAD 2002).

A general decrease in maize production is expected under climate change based on our crop yield modelling results. The average ranges of maize yield decrease for 2050s and 2090s compared to the baseline period (1971-2000) are $7 \%-14 \%$ and $13 \%-33 \%$, respectively (Fig.7). Erratic precipitation and temperature changes, and severe extreme events such as droughts and floods, coupled with population increase have already reduced maize production in Malawi for the past two decades despite government subsidies and continuous expansion in the cultivated area. In 2005, Malawi registered a very low national average maize production of 0.76 tons per hectare (t/ha), $40 \%$ below the expected average (Denning et al. 2009). Figure 8a shows Malawi's agricultural contribution to the overall GDP, indicating a good correlation between Malawi's economic growth and agricultural production. Figure $8 \mathrm{~b}$ shows
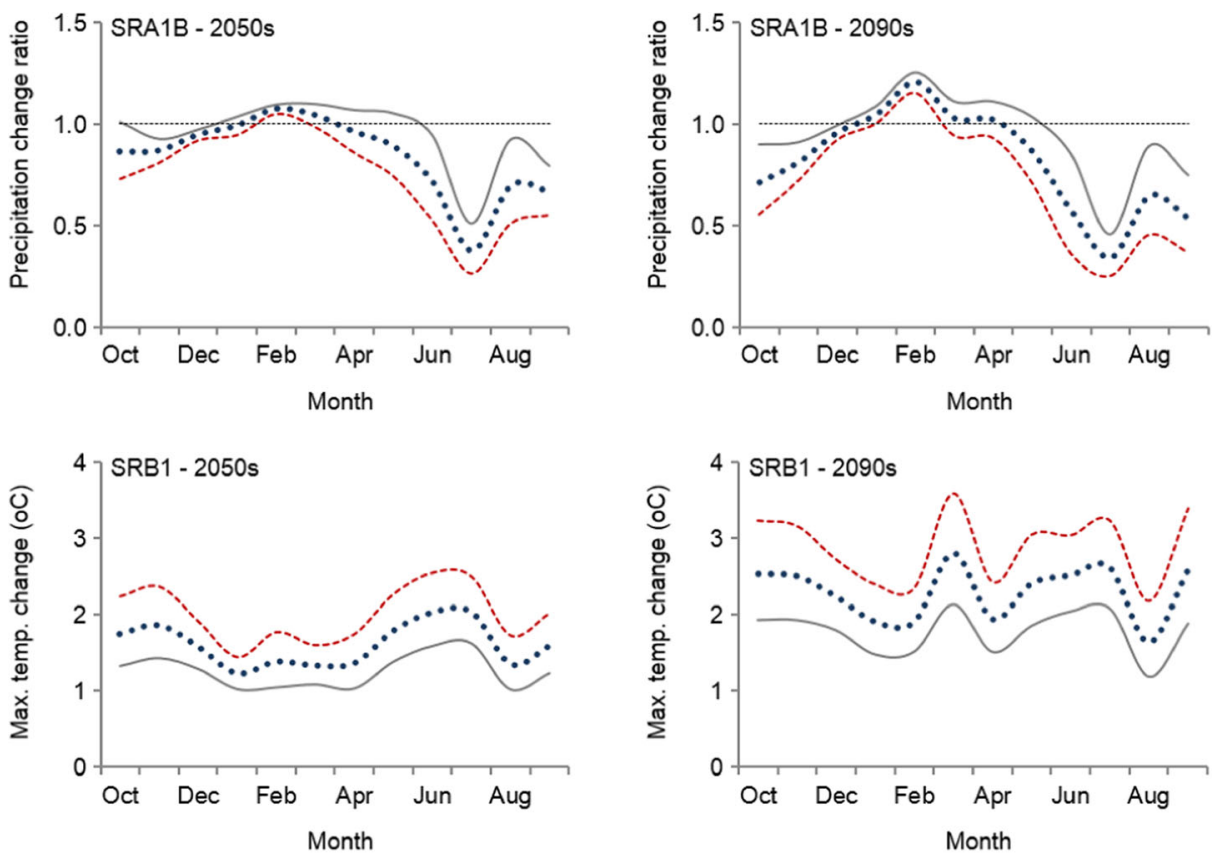

$25 \%$ probability percentile

$50 \%$ probability percentile

$75 \%$ probability percentile

No change (rainfall only)

Fig. 6 Changes in precipitation and maximum temperature by the mid-and end-century for the SRA1B and SRB1 emission scenarios with respect to the baseline values. The precipitation change ratio is the ratio of the projected to baseline precipitation in the same time of the year 

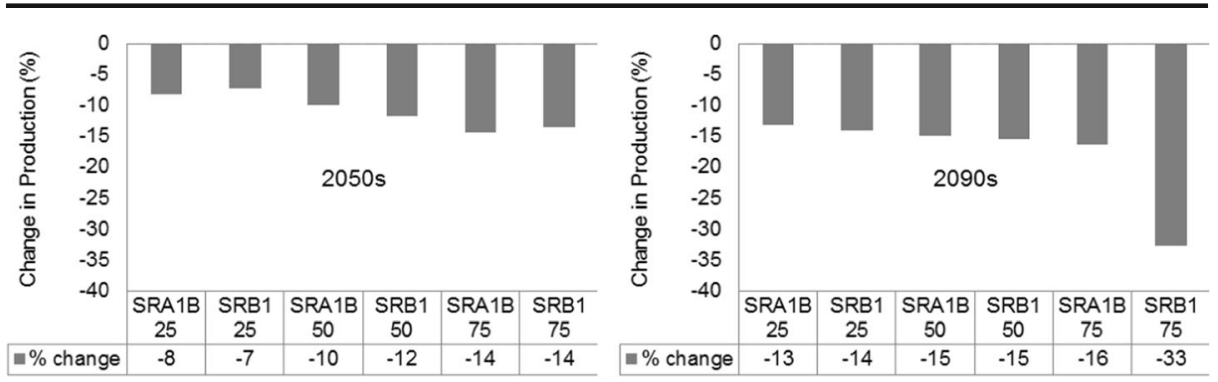

Fig. 7 Average changes in the Lilongwe District's mid- and late-century maize yields (\%)

the changes in maize production in Malawi from 1980 to 2011, illustrating the instability of maize production and a steady rise in maize prices over past decades. In the 1980's an average national production growth rate was $3 \%$, followed by a production decline rate of $2 \%$ per annum from 1990 to 1994 . The major drought of 1991-1992 heavily reduced maize production in this period and the following years. A series of positive and negative growth rates occurred from 1994 to 2000 resulting in a net $2.2 \%$ per annum. However, low precipitation and undesirable precipitation distribution between 2000 and 2005 decreased the national production potential of maize (Mapila et al. 2013). Steady increase in maize production occurred from 2005 to 2008 when the GoM introduced subsidy programs where subsistence farmers could buy farm inputs like fertilizer and seeds at a reduced rate.

\section{Discussion}

While the projected declines (Fig. 7) might seem modest, the ramifications for Malawi's food production and socioeconomic status could be substantial given the country's heavy reliance on rainfed agriculture and maize production for nutritional needs (Minot 2010), economic value (Mucavele 2006) and social importance (GoM 2011a). As maize becomes less affordable with the continued decline in yield, Malawi could face greater food insecurity, food shortages, and even famine. The situation is complicated by rapid population growth which has almost tripled since the late 1970's, currently growing at $3 \%$ a year and currently (2015) over 16 million (World Bank 2015) putting additional pressure on the diminishing food
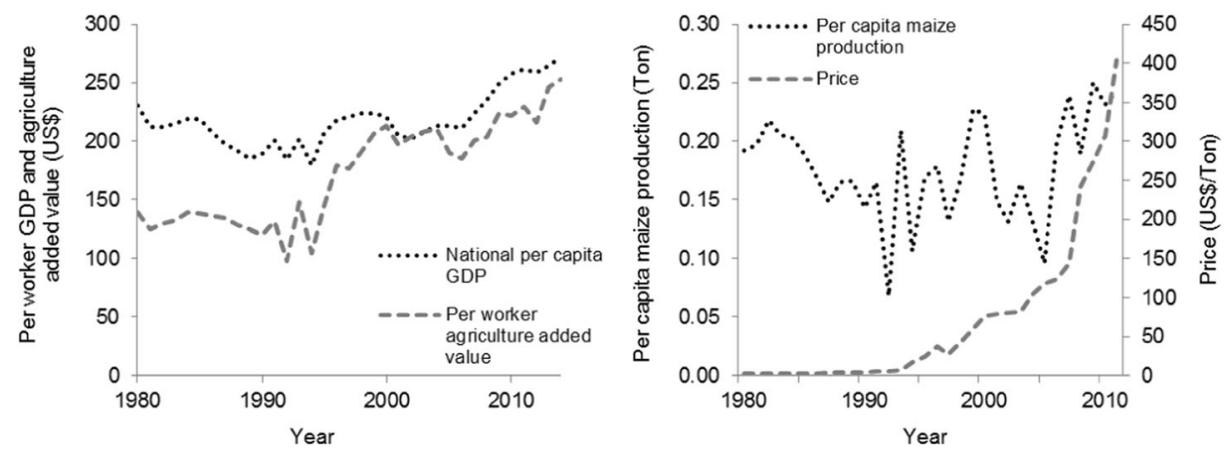

Fig. 8 Adjusted for constant 2005 prices a Malawi's per worker agricultural value-added and national per capita GDP for 1980-2008 (World Bank 2015); and b per capita maize production and price for the same period (Chirwa et al. 2006; FAOSTAT 2015; UN 2015; World Bank 2015) 
production. In the long-run, the reduced GDP due to unsustainable agricultural production can transfer additional stress to socioeconomic development. Internal population mobilization from declining farms to urban areas with relatively better employment prospects can ultimately increase over-crowded urban slums with poor living conditions. Increasing unemployment rate also can trigger labour out-migration from Malawi to neighbouring countries.

To improve national food security under climate change, the GoM could consider some adaptation strategies. Rainwater harvesting can supplement rainfed farming with irrigation (Lebel et al. 2015). Crop diversification and dietary changes could help with food insecurity. Food crops like cassava and sweet potatoes require less water than maize, have better resistance to climate change, and need less fertilizer (Chirwa et al. 2006). These strategies have been accepted and adopted in much of Africa (Tchale 2009). In 1998, Smaling reported that Malawian soils lose large amounts of nutrients (potassium, nitrogen and phosphorus) due to runoff and soil erosion (Tchale 2009). Land conservation methods like mulching and zero tilling could preserve soil fertility and improve crop yield (Dea and Scoones 2003). Research in biotechnology could help the sub-Saharan Africa region deal with climate change effects on agriculture through resistant crops (UNECA 2002). While some of the effects of climate change can be mitigated through these methods, industrial development of the country would be necessary to make this African nation less vulnerable to climate change. A growing industrial sector can prevent outmigration due to unemployment and can compensate for the major economic losses in the agricultural sector caused by climate change.

\section{Conclusion}

An evaluation of the impacts of climate change on rainfed maize production in Lilongwe District, Malawi was performed. Fifteen GCMs were used to estimate future climate variables in the mid- and end-century, under the SRA1B and SRB1 emission scenarios. Historical weather data from 1971 to 2000 were used as a baseline period.

Outputs from GCMs were downscaled using the LARS-WG, a widely used stochastic WG. A probability analysis assessment, using a bounded range with known probability distribution, was employed to handle the uncertainty of GCM outputs. Climate change variables were presented at three probability percentiles (25th, 50th, and 75th) representing varying risk levels of climate change. The FAO crop model, AquaCrop, was successfully calibrated, validated and used to simulate maize yields in future time periods.

We project that the mean annual precipitation in Lilongwe District will decrease by $0 \%$ to $26 \%$ and $3 \%$ to $29 \%$ in the mid- and end-century, respectively, compared to the baseline period of 1971-2000. However, mean monthly precipitation patterns depict both increase and decrease in different months and time periods. An overall increase in the mean monthly temperature is expected in both time horizons with maximum temperature changes in the ranges of $1.26{ }^{\circ} \mathrm{C}$ to $2.20{ }^{\circ} \mathrm{C}$ and $1.78{ }^{\circ} \mathrm{C}$ to $3.58{ }^{\circ} \mathrm{C}$ in the mid- and end-century, respectively. Crop modelling indicates that maize production will be reduced in the future by $-0.73 \%$ to $-14.33 \%$ by mid-century, and by $-13.19 \%$ to $-31.86 \%$ in the end of the century.

Acknowledgments The authors appreciate comments from Tilele Stevens. The first author acknowledges Fulbright scholarship from the United States Department of State Bureau of Educational and Cultural Affairs. 


\section{Compliance with Ethical Standards}

Conflict of Interest The authors declare that they have no conflict of interest.

Open Access This article is distributed under the terms of the Creative Commons Attribution 4.0 International License (http://creativecommons.org/licenses/by/4.0/), which permits unrestricted use, distribution, and reproduction in any medium, provided you give appropriate credit to the original author(s) and the source, provide a link to the Creative Commons license, and indicate if changes were made.

\section{References}

Abedinpour M, Sarangi A, Rajput T, Singh M, Pathak H, Ahmad T (2012) Performance evaluation of AquaCrop model for maize crop in a semi-arid environment. Agr Water Manage 110:55-66. doi:10.1016/j.agwat.2012.04.001

Allen RG, Pereira LS, Raes D, Smith M (1998) Crop evapotranspiration - Guidelines for computing crop water requirements. Food and agriculture organization irrigation and drainage paper 56. http://www.fao.org/ docrep/x0490e/x0490e00.htm. Accessed 03 August 2015

Burke MB, Miguel E, Satyanath S, Dykema JA, Lobell DB (2009) Warming increases the risk of civil war in Africa. Proc Natl Acad Sci USA 106:20670-20674. doi:10.1073/pnas.0907998106

Chavas DR, Izaurralde RC, Thomson AM, Gao X (2009) Long-term climate change impacts on agricultural productivity in eastern China. Agric for Meteorol 149:1118-1128. doi:10.1016/j.agrformet.2009.02.001

Chirwa EW, Jonathan K, Dorward A (2006) Future scenarios for agriculture in Malawi: challenges and dilemmas. Future Agricultures Consortium 2015. http://www.future-agricultures.org/publications/researchand-analysis/85-future-scenarios-for-agriculture-in-malawi/file. Accessed 03 August 2015

Dea D, Scoones I (2003) Networks of knowledge: how farmers and scientists understand soils and their fertility. A case study from Ethiopia. Oxf Dev Stud 31:461-478. doi:10.1080/1360081032000146636

Denning G, Kabambe P, Sanchez P, Malik A, Flor R, Harawa R, Nkhoma P, Zamba C, Banda C, Magombo C (2009) Input subsidies to improve smallholder maize productivity in Malawi: toward an African green revolution. PLoS Biol 7:2-10. doi:10.1371/journal.pbio.1000023

Dorward A, Chirwa E (2011) The Malawi agricultural input subsidy Programme: 2005-6 to 2008-9. Int J Agric Sustain 9:232-247. doi:10.3763/ijas.2010.0567

EAD (Environmental Affairs Department) (2002) Initial national communication of Malawi. Ministry of Natural Resources and Environmental Affairs. http://unfcc.int/resource/docs/natc/mwinc1.pdf. Accessed 03 August 2015

FAO (Food and Agriculture Organization) (2009) Introducing AquaCrop. Food and Agriculture Organization, Land and Water Division. http:/www.fao.org/nr/water/docs/IntroducingAquaCrop. pdf. Accessed 13 August 2015

FAOSTAT (Food and Agriculture Organization of the United Nations Statistics Division) (2015) FAOSTAT database, production: crops: maize. Food and Agriculture Organization. http://faostat3.fao.org/browse/Q/ QC/E. Accessed 16 August 2015

Fowler H, Blenkinsop S, Tebaldi C (2007) Linking climate change modelling to impacts studies: recent advances in downscaling techniques for hydrological modelling. Int J Climatol 27:1547-1578. doi:10.1002/joc.1556

Gohari A, Eslamian S, Abedi-Koupaei J, Bavani AM, Wang D, Madani K (2013) Climate change impacts on crop production in Iran's Zayandeh-Rud River basin. Sci Total Environ 442:405-419. doi:10.1016/j. scitotenv.2012.10.029

Gohari A, Bozorgi A, Madani K, Elledge J, Berndtsson R (2014) Adaptation of surface water supply to climate change in Central Iran. J Water Clim Chang 05:391-407. doi:10.2166/wcc.2013.189

GoM (Government of Malawi) (2011a) Annual economic report. Ministry of Development Planning and Cooperation 2015. http://psip.malawi.gov.mw/reports/docs/Economic_Report_2011.pdf. Accessed 31 July 2015

GoM (Government of Malawi) (2011b) The second national communication of the Republic of Malawi to the conference of the parties of the United Nations framework convention on climate change. Ministry of natural resources, energy, and environment; . http://unfccc.int/resource/docs/natc/mwinc2.pdf. Accessed 12 August 2015

Ines AV, Hansen JW (2006) Bias correction of daily GCM rainfall for crop simulation studies. Agric for Meteorol 138:44-53. doi:10.1016/j.agrformet.2006.03.009

IPCC (Intergovernmental Panel on Climate Change) (2007) Contribution of Working Groups I, II and II to the Fourth Assessment Report of the Intergovernmental Panel on Climate Change. IPCC. http://www.ipcc.ch/ pdf/assessment-report/ar4/syr/ar4_syr_full_report.pdf. Accessed 03 August 2015

Lebel S, Fleskens L, Forster PM, Jackson LS (2015) Lorenz, S (2015) Evaluation of in situ rainwater harvesting as an adaptation strategy to climate change for maize production in rainfed Africa. Water Resour Manage 29: 4803. doi:10.1007/s11269-015-1091-y 
Mapila MATJ, Kirsten JF, Meyer F, Kankwamba H (2013) A partial equilibrium model of the Malawi maize commodity market. IFPRI Discussion Paper 1254. http://ebrary.ifpri.org/cdm/ref/collection/p15738coll2/id/ 127473. Accessed 01 August 2015

MDCCMS (Malawian Department of Climate Change and Meteorological Services) (2015) Towards reliable, responsive and high quality weather and climate services in Malawi. http://www.metmalawi.com/. Accessed 03 August 2015

Mendelsohn R (2008) The impact of climate change on agriculture in developing countries. J of Nat Resour Pol Res 1:5-19. doi:10.1080/19390450802495882

Minot N (2010) Staple food prices in Malawi. International Food Policy Research Institute. http://ageconsearch. umn.edu/bitstream/58558/2/AAMP_Maputo_22_Malawi_ppr.pdf. Accessed 31 July 2015

Mucavele FG (2006) True Contribution of Agriculture to economic growth and poverty reduction: Malawi, Mozambique and Zambia synthesis report. Food Agriculture and Natural Resources Policy Analysis Network. http://www.fanrpan.org/documents/d01034/Synthesis. Accessed 31 July 2015

Muller C, Cramer W, Hare WL, Lotze-Campen H (2011) Climate change risks for African agriculture. P Natl Acad Sci USA 108:4313-4315. doi:10.1073/pnas.1015078108

Nakicenovic NS, Swart R (2000) Special report on emissions scenarios. Cambridge University Press, Cambridge

Ngingi SN (2009) Climate change adaptation strategies: Water resources management options for smallholder farming systems in Sub-Saharan Africa. The MDG Centre for East and Southern Africa, The Earth Institute at Columbia University. http://www.foresightfordevelopment.org/sobipro/55/197-climate-changeadaptation-strategies-water-resources-management-options-for-smallholder-farming-systems-in-subsaharan-africa. Accessed 03 August 2015

OECD (Organisation for Economic Co-operation and Development) (2004) Special issue on climate change: climate change policies: recent developments and long term issues. Organisation for Economic Co-operation and Development, Paris

Piani C, Weedon GP, Best M, Gomes SM, Viterbo P, Hagemann S (2010) Haerter JO. Statistical bias correction of global simulated daily precipitation and temperature for the application of hydrological models 395:199215. doi:10.1016/j.jhydrol.2010.10.024

Raes D, Steduto P, Hsiao TC, Fereres E (2012) Chapter 3. Calculation procedures. In: Raes D, Steduto P, Hsiao TC, Fereres E (eds) Reference manual AquaCrop version 4.0, Food and Agriculture Organization, Land and Water Division, Rome

Ringler C, Zhu T, Cai X, Koo J, Wang D (2010) Climate change impacts on food security in sub-Saharan Africa. International Food Policy Research Institute Discussion Paper 01042. http:/www.parcc-web.org/parccproject/documents/2012/12/climate-change-impacts-on-food-security-in-sub-saharan-africa.pdf. Accessed 03 August 2015

Schlenker W, Lobell DB (2010) Robust negative impacts of climate change on African agriculture. Environ Res Lett 5:1-8. doi:10.1088/1748-9326/5/1/014010

Semenov MA (2014) LARS-WG GCMs. Rothamstead Research. http://www.rothamsted.ac.uk/mas-models/ larswg/GCMs.htm. Accessed 12 August 2015

Semenov MA, Barrow, EM (2002) LARS-WG. A stochastic weather generator for use in climate impact studies. Rothamsted Research 2015 http://www.rothamsted.ac.uk/mas-models/download/LARS-WG-Manual.pdf. Accessed 03 August 2015

SMP (Scotland-Malawi Partnership) (2006) Socio-economic profile Lilongwe District (including district development planning framework). Scotland-Malawi Partnership. https://www.yumpu.com/en/document/view/ 5521830/socio-economic-profile-lilongwe-district-scotland-malawi-partnership. Accessed 13 August 2015

Steduto P, Hsiao TC, Raes D, Fereres E (2009) AquaCrop-the FAO crop model to simulate yield response to water: I. Concepts and underlying principles. Agron J 101:426-437. doi:10.2134/agronj2008.0139s

Tchale H (2009) The efficiency of smallholder agriculture in Malawi. AFJARE 3:01 August 2015-101-121

Tubiello F, Rosenzweig C, Goldberg R, Jagtap S, Jones J (2002) Effects of climate change on US crop production: simulation results using two different GCM scenarios. Part I: wheat, potato, maize, and citrus. Clim Res 20:259-270. doi:10.3354/cr020259

UN (United Nations) (2015) World population prospects, the 2015 revision. Department of Economic and Social Affairs. esa.un.org/unpd/wpp/DVD/. Accessed 16 August 2015

UNECA (United Nations Economic Commission for Africa) (2002) Harnessing technologies for sustainable development. economic commission for Africa. http://repository.uneca.org/handle/10855/1969. Accessed 01 August 2015

Walker N, Schulze R (2008) Climate change impacts on agro-ecosystem sustainability across three climate regions in the maize belt of South Africa. Agric Ecosyst Environ 124:114-124. doi:10. 1016/j.agee.2007.09.001

Wilby RL, Wigley T, Conway D, Jones P, Hewitson B, Main J, Wilks D (1998) Statistical downscaling of general circulation model output: a comparison of methods. Water Resour Res 34:2995-3008. doi:10.1029/98WR02577

World Bank (2015) World development indicators. Malawi. World Bank. http://data.worldbank.org/country/ malawi. Accessed 01 August 2015 